\title{
Outcome of Laser Surgery and Radiotherapy in Early Laryngeal Cancer
}

\author{
Rahman $\mathrm{MM}^{1}$, Siddiquee $\mathrm{BH}^{2}$, Karim $\mathrm{MA}^{3}$, Rahman $\mathrm{T}^{4}$, Nihar F $\mathrm{F}^{5}$, Kamal $\mathrm{MS}^{6}$.
}

\begin{abstract}
The study was undertaken to compare between surgery and radiotherapy in early carcinoma larynx (T1N0). 60 cases of early carcinoma larynx were selected purposive sampling technique from all the patients of carcinoma larynx admitted into Otolaryngology and Head-Neck Surgery Department of Bangabandhu Sheikh Mujib Medical University,Dhaka; Dhaka Medical College Hospital,Dhaka; Shaheed Suhrawardy Medical College Hospital, Dhaka; Taqwah Specialized Hospital,Dhaka from January 2010 to June 2011. Carcinoma of the larynx is the most common cancer affecting the head and neck region. The main aim of this study was to determine whether there was any difference in the two main therapeutic options. The secondary aim was to assess speech and voice quality in a small, randomized sample of patients from each treatment group.
\end{abstract}

The subjects investigated were 60 patients with $T_{1} N_{0}$ squamous cell carcinoma of the larynx. 30 patients were treated by irradiation, and 30 were treated with surgery. The primary outcome measures were recurrence at the primary site, recurrence in the neck. The secondary outcome measure was speech and voice quality. Surgery included laser assisted partial laryngectomy and various minor procedures on the glottis, including cordectomy. Surgery was more likely to be carried out for supraglottic disease.

Result showed $16.67 \%$ of the irradiation group had a primary site recurrence compared with $20.0 \%$ in the surgery group at $12^{\text {th }}$ months $(p=0.59)$ and $6.67 \%$ of those who were treated with irradiation had a recurrence in the neck. $16.67 \%$ of patients in the surgery group had a recurrence in the neck $(p<0.05)$. There was no significant difference in primary site recurrence rates for the two treatment modalities, but regional recurrence was higher in the surgery group.

1. Corresponding Author : Md. Mostafizur Rahman Junior Consultant (ENT)

Upazilla Health Complex, Srinogor, Munshigonj, Bangladesh.

2. Belayat Hossain Siddiquee

Professor, Department of Otolaryngology \& Head-Neck Surgery Bangabandhu Sheikh Mujib Medical University, Dhaka

3. Md. Afzal Karim

Registrar, Department of Otolaryngology \& Head-Neck Surgery

Sher-e-Bangla Medical College Hospital, Barisal

4. Tawfiqur Rahman

Medical Officer, Department of Otolaryngology \& Head-Neck Surgery

Bangabandhu Sheikh Mujib Medical University, Dhaka

5. Fatema Nihar

Assistant Surgeon

Bagra Union Health Sub-center, Shrinogor, Munshigonj

6. Mohammad Shah Kamal

Junior Consultant, Shaheed Samsuddin Ahmed Hospital

(Sadar Hospital) Sylhet, Bangladesh.
Regarding speech and voice quality, radiotherapy was far superior to surgery. All patients in the radiotherapy group but only 3 of 10 in the surgery group were judged to have a good or normal voice $(p=.0017)$.

Both surgery and irradiation are equally effective at treating early laryngeal carcinoma but Speech and voice quality were significantly better in patients treated by irradiation than those treated by surgery.

\section{Keywords}

Partial laryngectomy; conservative laryngectomy; speech and voice quality; head and neck cancer; squamous cell carcinoma

\section{Introduction}

Cancer of the larynx is the most common cancer of the head and neck, excluding the skin. ${ }^{1}$ It would seem that early laryngeal cancer could be treated with equal success by either radiotherapy or by conservative surgery. ${ }^{2-8}$ The preferred treatment modality at present is highly dependent on geography, with radiotherapy tending to be the treatment of choice in northern Europe, whereas patients are more likely to be treated with surgery in the United States and southern Europe. Organ preservation strategy favoring primary radical radiotherapy followed, if necessary, by salvage surgery. This strategy evolved over the years is based on the premise that treatment goals should include cure with acceptable side effects, minimal complications, and laryngeal preservation. Irradiation treatment failures can usually be salvaged by total or partial laryngectomy. The data for this article have been collected in a prospective manner over a period of one year. During the last two decades, radiotherapy gradually superseded surgery as the treatment of choice, and thus we are able to compare the results of surgery with radiotherapy for the treatment of early laryngeal cancer. The aim of this article is therefore to compare the results of the two treatment modalities in terms of recurrence at the site of the primary tumor, in the neck. Associations between variables were also studied. A small, intercalated study investigates speech and voice quality in patients from each treatment modality.

\section{Materials \& Methods}

Type Of Study : Cross sectional study

Place Of Study : Department of Otolaryngology and Head-Neck Surgery, Bangabandhu Sheikh Mujib Medical University,Dhaka, Shaheed Suhrawardy Medical College\&Hospital,Dhaka, Dhaka Medical college hospital,Dhaka,Taqwah Specialized Hospital,Dhaka.

Period Of Study : January' 2010 to June' 2011

Study Population : All consecutive cases of carcinoma admitted in the above hospital during the study period.

Methods of sampling : Patients suspected of carcinoma of the larynx are evaluated properly by detailed history taking,clinical examination and relevent investigation. 
Technique of Treatment: laser surgery and radiotherapy.

Post operative follow up: All the patients were followed up after 2 weeks, 1 month and then three monthly for one year

\section{Operational Definition}

Major morbidity- which significantly hampered the patients quality of life like haematoma, seroma, flapnecrosis, stomal recurrence, stenosis of the tracheostomy, recurrent chest infections, distal metastasis, pharyngeal stenosis in partial laryngectomy patients. Severe radiation reaction necrosis of skin, respiratory distress following radiation and perichondritis of the larynx in radiotherapy.

Minor morbidity- Unavoidable minor complications like wound infection, nausea, vomiting, skin rashes, alopecia, mucositis or painful erythematous reaction in larynx and pharynx, dryness of mouth and throat, loss of taste, subcutaneous fibrosis in radiotherapy.

\section{Intercalated Study of Voice Quality}

We comparing the voice quality of patients from the two treatment groups. Randomly 10 patients from each treatment group ware selected. The patients in the radiotherapy group were older (mean age, 56 years) than those in the surgery group (mean age, 52 years). There were no other significant differences between the two groups. Voice and speech quality was assessed by a simple scoring system Voice Handicap Index (VHI score) validated in standard questionnaires* The scoring method was a simple 4-point score.

1. Normal voice and speech (score $0-10)$.

2. Good voice and speech (score 11-30).

3. Moderate voice and speech (score 31-50).

4. Poor voice and speech (score $>50$ ).

\section{Results}

Table-I: Age distribution of the patients $(n=60)$

\begin{tabular}{lccc}
\hline $\begin{array}{c}\text { Age group (in } \\
\text { years) }\end{array}$ & $\begin{array}{c}\text { Radiotherapy } \\
(\mathbf{n}=\mathbf{3 0})\end{array}$ & $\begin{array}{c}\text { Surgery } \\
(\mathbf{n}=\mathbf{3 0})\end{array}$ & P value \\
\hline $30-39$ & $2(6.67 \%)$ & $3(10.0 \%)$ & $0.145^{\mathrm{NS}}$ \\
$40-49$ & $7(23.33 \%)$ & $6(20.0 \%)$ & \\
$50-59$ & $10(34.2 \%)$ & $14(46.67 \%)$ & \\
$60-69$ & $7(23.33 \%)$ & $5(16.67 \%)$ & \\
$70-79$ & $4(13.33 \%)$ & $2(6.67 \%)$ \\
& & \\
Mean \pm SD & $55.96 \pm 10.52$ & $52.03 \pm 10.11$ \\
\hline
\end{tabular}

Table shows The age of the patient ranged from 30 to 79 year. The mean \pm SD age was $(54 \pm 10.94)$ most of the patients were above 40 years of age. The mean age of the radiotherapy group was 56 years, and the mean age for the surgical group was 52 years.
Table-II: Sex distribution of the subject $(n=60)$

\begin{tabular}{cccc}
\hline Sex & $\begin{array}{c}\text { Radiotherapy } \\
(\mathbf{n = 3 0}) \text { No. }(\%)\end{array}$ & $\begin{array}{c}\text { Surgery }(\mathbf{n}=30) \\
\text { No. }(\%)\end{array}$ & P value \\
\hline Male & 26(87.6\%) & $28(93.33 \%)$ & $0.38^{\mathrm{NS}}$ \\
Female & $4(13.33)$ & $2(6.67 \%)$ & \\
\hline
\end{tabular}

Table shows that out of 30 cases 26 were male in radiotherapy group and out of 30 cases 28 were male in surgery group. Almost all cases were male.There was no significant diffirence in male-female ratio for the two groups.

Table-III: Habit of the patients carcinoma of larynx $(n=60)$

\begin{tabular}{lcc}
\hline \multicolumn{1}{c}{ Habit } & $\begin{array}{c}\text { Radiotherapy } \\
\text { No. }(\%)\end{array}$ & $\begin{array}{c}\text { Surgery No. } \\
(\mathbf{\%})\end{array}$ \\
\hline Smoking & $29(96.67 \%)$ & $28(93.33 \%)$ \\
Drinking alcohol & $1(3.33 \%)$ & $2(6.67 \%)$ \\
Chewing betel nut \& & $28(93.33 \%)$ & $29(96.67 \%)$ \\
tobacco & & \\
$\begin{array}{l}\text { Chewing betel nut, tobacco } \\
\text { \& smoking }\end{array}$ & $15(50.0 \%)$ & $13(43.33 \%)$ \\
\hline
\end{tabular}

Table shows that out of 30 cases 29 were smokers in radiotherapy group and 28 were in surgery group, 28 cases were habituated with chewing betel nut and tobacco in radiotherapy group 29 in surgery group.On the otherhand $50 \%$ patients in radiotherapy group had the habit of Chewing betel nut, tobacco \& smoking and surgery group it was $43.33 \%$.

Table-IV: Site of carcinoma on the basis of fiber optic laryngoscopy and direct laryngoscopic findings $(n=60)$

\begin{tabular}{lccc}
\hline $\begin{array}{c}\text { Site of } \\
\text { carcinoma } \\
\text { larynx }\end{array}$ & $\begin{array}{c}\text { Radiotherapy } \\
(\mathbf{n = 3 0}) \text { No. }(\%)\end{array}$ & $\begin{array}{c}\text { Surgery } \\
(\mathbf{n = 3 0 )}) \\
(\%)\end{array}$ & P value \\
\hline Supraglottic & $18(60.0 \%)$ & $20(66.67 \%)$ & $.787^{\mathrm{NS}}$ \\
Glottic & $12(40.0 \%)$ & $10(33.33 \%)$ & \\
Subglottic & 0 & 0
\end{tabular}

Table shows that supgraglottic carcinoma was found in $60 \%$ of radiotherapy group and $66.67 \%$ in surgery group, glottic carcinoma was $40 \%$ \& 33\%,respectively in radiotherapy and surgery group. No case found with subglottic carcinoma. There was no significant diffirence in these two groups regarding site of carcinoma. 
Table-V: Histopathological grading of carcinoma larynx $(n=60)$

\begin{tabular}{|c|c|c|c|}
\hline Degreeofdifferentiation & $\begin{array}{l}\text { Radiotherapy } \\
\begin{array}{c}(\mathrm{n}=\mathbf{3 0}) \text { No. } \\
(\%)\end{array}\end{array}$ & $\begin{array}{c}\begin{array}{c}\text { Surgery } \\
(n=30) \text { No. } \\
(\%)\end{array} \\
\text { (\%) }\end{array}$ & $\begin{array}{c}P \\
\text { value }\end{array}$ \\
\hline Well differentiated (grade- I) & $7(23.33 \%)$ & $6(20.0 \%)$ & $0.411^{\mathrm{NS}}$ \\
\hline $\begin{array}{l}\text { Moderately differentiated } \\
\text { (grade-II) }\end{array}$ & $18(60.0 \%)$ & $18(60.0 \%)$ & \\
\hline $\begin{array}{l}\text { Poorly differentiated } \\
\text { (grade-III) }\end{array}$ & $5(16.67 \%)$ & $6(20.0 \%)$ & \\
\hline Undifferentiated (grade-IV) & 0 & 0 & \\
\hline
\end{tabular}

Table shows that histopathological examination: Well differentiated was found $23.33 \%$ in radiotherapy group and $20 \%$ were in surgery group and moderately differentiated carcinoma was $60 \% \& 16.67 \%$, poorly differentiated carcinoma was $6(20.0 \%)$ \& $2(6.67 \%)$. There was no significant diffirence in these two groups- Majority of the subject belong to grade-II.

Table-VI: Complications of radiotherapy and surgery

\begin{tabular}{|c|c|c|c|}
\hline \multicolumn{4}{|l|}{ Surgery } \\
\hline $\begin{array}{c}\text { Major } \\
\text { complications }\end{array}$ & $\begin{array}{l}\text { No. } \\
(\%)\end{array}$ & $\begin{array}{c}\text { Minor } \\
\text { complictions }\end{array}$ & No. (\%) \\
\hline Haematoma & $\begin{array}{c}2 \\
(6.67 \%)\end{array}$ & $\begin{array}{l}\text { Tracheal } \\
\text { crusting }\end{array}$ & $1(3.33 \%)$ \\
\hline Seroma & $\begin{array}{c}1 \\
(3.33 \%)\end{array}$ & & \\
\hline $\begin{array}{l}\text { Pharyngeal } \\
\text { stenosis }\end{array}$ & $\begin{array}{c}2 \\
(6.67 \%)\end{array}$ & & \\
\hline $\begin{array}{l}\text { Recurrent chest } \\
\text { infection }\end{array}$ & $\begin{array}{c}1 \\
(3.33 \%)\end{array}$ & & \\
\hline \multicolumn{4}{|l|}{ Radiotherapy } \\
\hline $\begin{array}{c}\text { Major } \\
\text { complications }\end{array}$ & $\begin{array}{l}\text { No. } \\
(\%)\end{array}$ & $\begin{array}{c}\text { Minor } \\
\text { complictions }\end{array}$ & No. (\%) \\
\hline $\begin{array}{l}\text { Severe radiation } \\
\text { necrosis of skin }\end{array}$ & $\begin{array}{c}1 \\
(3.33 \%)\end{array}$ & $\begin{array}{l}\text { Mucositis } \\
\text { or painful } \\
\text { erythematous } \\
\text { reaction in } \\
\text { larynx and } \\
\text { pharynx }\end{array}$ & $3(10.0 \%)$ \\
\hline $\begin{array}{l}\text { Respiratory } \\
\text { distress following } \\
\text { radiotherapy }\end{array}$ & $\begin{array}{c}1 \\
(3.33 \%)\end{array}$ & $\begin{array}{l}\text { Dryness of } \\
\text { mouth and } \\
\text { throat }\end{array}$ & $15(50.0 \%)$ \\
\hline \multirow[t]{3}{*}{ Perichondritis } & $\begin{array}{c}1 \\
(3.33 \%)\end{array}$ & Loss of taste & $3(10.0 \%)$ \\
\hline & & $\begin{array}{l}\text { Subcutaneous } \\
\text { fibrosis }\end{array}$ & $2(6.67 \%)$ \\
\hline & & Dysphagia & $4(13.33 \%)$ \\
\hline
\end{tabular}

Table shows in surgery group 2 patients had haematoma, 2 patients had pharyngeal stenosis and 1 patien had tracheal crusting. In radiotherapy group 3 patients had major complications and 27 patients hand minor complications most of them were dryness of mouth and throat.
Table-VII: Morbidity due to surgery and radiotherpay $(\mathrm{n}=60)$

\begin{tabular}{lccc}
\hline Morbidities & Radiotherapy & Surgery & P value \\
\hline $\begin{array}{l}\text { Major } \\
\text { morbidities }\end{array}$ & 3 & 6 & 0.471 \\
$\begin{array}{l}\text { Minor } \\
\text { morbidities }\end{array}$ & 27 & 1 & 0.001 \\
\hline
\end{tabular}

Table shows that major morbidities and minor morbidities for surgery were 6 and 1 respectively and major morbidities \& minor morbidities for radiotherapy were 3 and 27 respectively.

Table-VIII: Distribution of Voice Handicap Index (VHI) scores of patients treated early carcinoma larynx as related to treatment modality

\begin{tabular}{lccc}
\hline VHI score & $\begin{array}{c}\text { Radiotherapy } \\
(\mathbf{n}=\mathbf{1 0})\end{array}$ & $\begin{array}{c}\text { Surgery } \\
(\mathbf{n}=\mathbf{1 0})\end{array}$ & P value \\
\hline Normal voice (0-10) & 8 & 0 & $0.001^{\mathrm{s}}$ \\
Good voice (11-30) & 2 & 3 & \\
Moderate voice (31-50) & 0 & 4 & \\
Poor voice $(>50)$ & 0 & 3
\end{tabular}

Table shows that ten patients from each treatment group were recruited randomly. In the radiotherapy group, eight were scored as normal and two as good. For the surgery group, three patients had good voice and speech, four had moderate voice and speech, and three had poor voice and speech. This difference was ststistically significant $(p=.001)$.

Table-IX: Proportion of patients developing a primary site reuccrence for the two treatment modalities

\begin{tabular}{lccc}
\hline $\begin{array}{c}\text { Time of recurrence } \\
\text { (months) }\end{array}$ & Radiotherapy & Surgery & P value \\
\hline $6^{\text {th }}$ months & $2(6.67 \%)$ & $3(10.0 \%)$ & $0.59^{\mathrm{NS}}$ \\
$9^{\text {th }}$ months & $3(10.0 \%)$ & $4(13.33 \%)$ & \\
$12^{\text {th }}$ months & $5(16.67 \%)$ & $6(20.0 \%)$ & \\
\hline
\end{tabular}

Table shows that no significant difference was found when recurrence at the primary site for those patients treated by surgery or by irradiation was studied. $16.67 \%$ of the irradiation group had a primary site recurrence compared with $20.0 \%$ in the surgery group at $12^{\text {th }}$ months $(\mathrm{p}=0.59)$. 
Table-X : Proportion of patients developing a node in the nekc for the two treatment modalities

\begin{tabular}{lccc}
\hline $\begin{array}{c}\text { Time of recurrence } \\
\text { (months) }\end{array}$ & Surgery & Radiotherapy & P value \\
\hline $6^{\text {th }}$ months & $1(3.33 \%)$ & 0 & $0.05^{\mathrm{s}}$ \\
$9^{\text {th }}$ months & $3(10.0 \%)$ & $1(3.33 \%)$ & \\
$12^{\text {th }}$ months & $5(16.67 \%)$ & $2(6.67 \%)$ & \\
\hline
\end{tabular}

Table shows that there was a significant difference in the pattern of recurrence in the neck between the two treatment groups. Only $6.67 \%$ of those who were treated with irradiation had a recurrence in the neck. $16.67 \%$ of patients in the surgery group had a recurrence in the neck; this difference was statistically significant $(\mathrm{p}<0.05)$.

\section{Discussion}

The host and tumor factors for both treatment groups are shown in Table 1-2. The mean age of the radiotherapy group was 63 years, and the mean age for the surgical group was 61 years. There was no significant difference in male-female ratio for the two groups.

Among all the aeteological factors, smoking, habitual in chewing betel nuts and betel leaves and alcohol are the most important factors contributing to the carcinoma larynx. Out of 30 cases $96.67 \%$ were smokers in radiotherapy group and $93.33 \%$ were in surgery group, $93.33 \%$ cases were habituated with chewing betel nut and tobacoo and only $50.0 \%$ and $43.33 \%$ cases were both chewing and smoker in Radiotherapy and Surgery groups respectively.

The findings of direct laryngoscopy showed supgraglottic carcinoma was found $60 \%$ in radiotherapy group and $66.67 \%$ were in surgery group and glottic carcinoma was $(40 \%$ \& $33 \%$ ) only. No case was found with subglottic carcinoma. The nature of lesion was exophytic in $(66.67 \%$ \& $63.33 \%)$ and ulcerative $(33.33 \% \& 36.67 \%)$. There was no significant diffirence between the two Regarding histopathological examination 95\% were squamous variety, similarity was seen by anather study 16 There was no significant diffirence in these two groups- Majority of the subject

Among the total 60 study cases, 30 cases were treated by laser surgery and 30 cases were treated by radiotherapy.

In this study showed out of 30 cases in surgery group 6 patients had major complications most of them were pharyngeal stenosis $2(6.67 \%)$ and 1 patien had minor complications. In radiotherapy group 3 patients had major complications and 27 patients hand minor complications most of them were dryness of mouth and throat.

Wound infection 30\% in surgery group Haematoma 6.67\%, seroma $3.33 \%$ Pharyngeal stenosis $6.67 \%$ were near to other study Haematoma $8.82 \%$, seroma 3\%, Pharyngeal stenosis $5 \% .^{17}$

Among the 30 cases of radiotherapy patient developed several side effect of radiotherapy, dryness of mouth and throat, loss of taste, pigmentation of skin and subcutaneous fibrosis during study period. Another study reveals the same type of morbidity of acute radiation like difficulty in tasting food $76.3 \%$, dryness of mouth $92 \%$ and changes in taste and dryness of mouth. ${ }^{18}$

Post radiotherapy $10.0 \%$ patients develop mucositis in larynx and pharynx, $3.33 \%$ developed severe reaction necrosis of skin, $3.33 \%$ developed respiratory distress following radiotherapy, $50 \%$ patients developed dryness of mouth and throat, and loss of taste, $6.67 \%$, patients developed subcutaneous firbosis.

These type of morbidity due to radiation also reveals in another study ${ }^{19}$. They reported pain and soreness of mouth in $86.8 \%$, pain and itching of the skin in $86.8 \%$, difficulty in chewing in $55.3 \%$ cases.

This study showed that Regarding speech and voice 10 patients from each treatment group were recruited randomly by using computer. In the radiotherapy group, 8 were scored as normal and 2 as good. For the surgery group, three patients had good voice and speech, 4 had moderate voice and speech, and 3 had poor voice and speech. This result coincides by another study. ${ }^{20}$

In this study that no significant difference was found when recurrence at the primary site for those patients treated by surgery or by irradiation was studied. $16.67 \%$ of the irradiation group had a primary site recurrence compared with $20.0 \%$ in the surgery group at $12^{\text {th }}$ months $(p=0.59)$. This result coincides by another study ${ }^{20}$, where primary site recurrence were $20 \%$ in radiotherapy group and $22 \%$ in surgery group.

This study showed that there was a significant difference in the pattern of recurrence in the neck between the two treatment groups. Only $6.67 \%$ of those who were treated with irradiation had a recurrence in the neck. $16.67 \%$ of patients in the surgery group had a recurrence in the neck. This result coincide by another study $9.0 \%$ of radiotherapy group at primary site recurrence and $25.0 \%$ in surgery group. ${ }^{20}$

Both surgery and irradiation are equally effective at treating early laryngeal carcinoma but Speech and voice quality were significantly better in patients treated by irradiation than those treated by surgery.

\section{References}

1. Ferlito A. The natural history of early vocal cord cancer. Acta Otolaryngol (Stockh) 1995;115:345-347.

2. Amornmarn R, Prempreet T, Viravathana T, et al. A therapeutic approach to early vocal cord carcinoma. Acta Radiol Oncol 1985;4:321-325. 
3. Dickens W, Cassisi N, Millon R, et al. Treatment of early vocal cord carcinoma: a comparison of apples with apples. Laryngoscope 1983;93:216-219.

4. Harwood A, Hawkins N, Keane T, et al. Radiotherapy of early glottic cancer. Laryngoscope 1980;90:465-470.

5. Sinha P. Radiation therapy in early carcinoma of the true vocal cords (stage I and II). Int J Radiat Oncol Biol Phys 1987;13:1635-1640.

6. Rothfield R, Johnson J, Myers E, et al. The role of hemilaryngectomy in the management of $\mathrm{T} 1$ vocal cord cancer. Arch Otolaryngol Head Neck Surg 1989;115:677-680.

7. Neel HB III, Devine K, DeSanto L. Laryngofissure and cordectomy for early cordal carcinoma: outcome in 182 patients. Otolaryngol Head Neck Surg 1980;88:79-84.
8. DeSanto L, Devine K, Lillie J. Cancers of the larynx: glottic cancer. Surg Clin North Am 1977;57:611-620.

9. Burstein FD, Calcaterra TC. Supraglottic laryngectomy: series report and analysis of results. Laryngoscope 1985; 95:833-866.

10. Suarez C, Rodrigo JP, Herranz J, et al. Supraglottic laryngectomy with or without postoperative radiotherapy in supraglottic carcinomas. Ann Otol Rhinol Laryngol 1995; 104:358-363.

11. Sheen T-S, Ko J-Y, Chang Y-L. Partial vertical laryngectomy in the treatment of early glottic cancer. Ann Otol Rhinol Laryngol 1998;107:593-597.

12. Thomas JV, Olsen KD, Neel HB III, et al. Early glottic carcinoma treated with open laryngeal procedures. Arc. Otolaryngol Head Neck Surg 1994;120:264-268. 